\title{
L-Lysine Decarboxylase as a Specific Inhibitor of the Growth of a Species of Pichia*
}

\author{
By R. I. LEAVITT AND F. X. R Y AN \\ Mobil Research and Development Corporation, Central Research Division, \\ P.O. Box 1025, Princeton, New Jersey 08540, U.S.A.
}

(Received 29 May 1973; revised I6 July 1973)

In conjunction with our interest in single-cell protein (Coty \& Leavitt, I971), a search was made for a screen which would supply a selection pressure for the isolation of a strain of yeast capable of excreting lysine during growth on hydrocarbons. Initially, we hoped to isolate over-producers by selecting for resistance to analogue of L-lysine, but failed because none of the analogues examined, either alone or in conjunction with compounds which were used to affect yeast-wall permeability, had any effect on the growth of our yeast. The use of L-lysine decarboxylase was then examined and found to be a successful means for inhibiting growth. The results of this study and its possible implications are discussed below.

\section{METHODS}

The yeast used was a member of the genus Pichia. The medium used for growth consisted of (g/l of water): $\left(\mathrm{NH}_{4}\right)_{2} \mathrm{SO}_{4}, 2 \cdot 0 ; \mathrm{MgSO}_{4} \cdot 7 \mathrm{H}_{2} \mathrm{O}, 0 \cdot 2 ; \mathrm{Na}_{2} \mathrm{HPO}_{4}, 3 \cdot 0 ; \mathrm{KH}_{2} \mathrm{PO}_{4}, 2 \cdot 0 ; \mathrm{CaCl}_{2}$, $0.0 \mathrm{I} ; \mathrm{Na}_{2} \mathrm{CO}_{3}, \mathrm{O} . \mathrm{I} ; \mathrm{FeSO}_{4} .7 \mathrm{H}_{2} \mathrm{O}, 0.005 ; \mathrm{MnSO}_{4}, 0.002 ; \mathrm{CoCl}_{2}, 0.002 ; \mathrm{Na}_{2} \mathrm{Mo}_{4}, 0.002$.

Either $2 \%(\mathrm{w} / \mathrm{v})$ glucose or $n$-hexadecane was used as a sole carbon and energy source.

Pediococcus cereviseae (ATCC 8042) was used to assay for the presence of L-lysine.

L-Lysine decarboxylase was purchased from Calbiochem, London W. I. In the inhibition studies $0 \cdot 0 \mathrm{r} \mathrm{ml}$ of the decarboxylase $(5 \mathrm{mg} / \mathrm{ml})$ was added to a filter paper disc $(1 \cdot 0 \mathrm{~cm}$ diam.) which had previously been placed on the surface of an agar plate. In the experiment in which the growth of Pediococcus cereviseae was inhibited, the agar contained all the nutrients required for growth including lysine (Steele, Sauberlich, Reynolds \& Baumann, 1949). When the yeast was cultured the mineral-salts agar was supplemented with glucose $(2 \cdot 0 \% \mathrm{w} / \mathrm{v})$. Bioassay was performed by measuring the diameters of the growth zones and relating these to the amounts of lysine present in the agar media.

Mutants resistant to the activity of L-lysine decarboxylase were isolated by impregnating a Millipore filter disc ( $0.8 \mu \mathrm{m}$ pore diam.) with the enzyme and covering the disc with a thin layer of glucose-mineral-salts agar contained in a Petri dish (100 $\mathrm{mm} \times 10 \mathrm{~mm}$ ). A droplet containing hydrocarbon-grown Pichia was smeared in a $2 \mathrm{~mm}$ streak across the agar directly over the enzyme-impregnated disc. After $\mathrm{I} 7 \mathrm{~h}$ incubation at $34{ }^{\circ} \mathrm{C}$, colonies which grew more rapidly than the background of inhibited organisms were removed and purified by subculturing in the absence of the decarboxylase.

Thin-layer chromatography of the amino acids was performed by using silica-gel plates and developing in a butanol-acetic acid-water solvent ( $4: \mathrm{I}: 1)$. Amino acids were detected by spraying the developed plates with a $0.2 \%$ acetone solution of ninhydrin. The free amino acid was extracted from washed yeast by boiling in water for $30 \mathrm{~min}$.

* An abstract of this paper was presented at the 1972 Annual Meeting of the American Society for Microbiology. 
Table I. L-Lysine detected in the media, amino-acid pool and protein of decarboxylase-sensitive (wild) and resistant (mutant) yeast

\begin{tabular}{|c|c|c|c|}
\hline Organism & $\begin{array}{c}\text { Medium } \\
\text { (mg/l excreted) }\end{array}$ & $\begin{array}{c}\text { Protein } \\
(\mu \mathrm{g} / \mathrm{mg} \text { cell })\end{array}$ & $\begin{array}{c}\text { Pool } \\
(\mu \mathrm{g} / \mathrm{mg} \text { cell })\end{array}$ \\
\hline PW (Wild type) & 0.5 & $3 \cdot 0$ & 30 \\
\hline PA ) Mutant & $5^{\circ} 0$ & $5 \cdot 2$ & 40 \\
\hline PB (10) & $2 \cdot 3$ & - & 一 \\
\hline PC J (ypes) & $2 \cdot 3$ & - & - \\
\hline
\end{tabular}

Protein was extracted according to Roberts et al. (1963) and hydrolysed in $6 \mathrm{~N}-\mathrm{HCl}$ by heating for $17 \mathrm{~h}$ in sealed ampoules at $150^{\circ} \mathrm{C}$.

\section{RESULTS AND DISCUSSION}

The L-lysine requirer, Pediococcus cereviseae (ATCC 8042), was grown in the presence of a decarboxylase-treated disc on an amino-acid supplemented agar medium in order to demonstrate that L-lysine decarboxylase could degrade lysine at a rate which was rapid enough to inhibit the multiplication of an organism whose growth depended on the presence of the amino acid. After overnight incubation, growth was observed in all areas of the plate except the area immediately under the disc and $3 \mathrm{~mm}$ beyond its periphery. No inhibition of growth occurred in another test in which a filter disc was impregnated with both the decarboxylase and an excess of lysine.

In similar tests using Pichia in a glucose-mineral-salts agar plate system growth was again observed in all areas of the plate except under and immediately adjacent to the decarboxylase filter disc. The specificity of the inhibition was confirmed by the absence of a zone of inhibition in a second plate in which both the decarboxylase and $0.01 \mathrm{ml}$ of a solution containing $2.5 \mathrm{mg}$ of $\mathrm{L}$-lysine $/ \mathrm{ml}$ were added to the same filter disc. Also, the same concentration of cadaverine, the product of lysine decarboxylation, failed to inhibit the growth of the yeast, thereby demonstrating that it was the actual loss of lysine rather than a secondary effect which was responsible for the growth-inhibiting activity of the decarboxylase.

Five of the mutants resistant to the activity of the enzyme were subcultured and examined for lysine excretion. Three of these mutants excreted more lysine (determined both chromatographically and by bioassay) than the parent yeast when grown in a mineral-salts medium with $n$-hexadecane as the source of carbon (Table I). L-Lysine in the free amino-acid pool and protein lysine in the sensitive and one of the resistant organisms (PA) were estimated (Table I). In both the pool and protein hydrolysates, lysine was found by bioassay to be higher in the organism whose growth was unaffected by the action of the decarboxylase. Both organisms contained the same amount of protein ( $50 \%$ of the dry wt) and lysine was the only amino acid to be found in excess by paper-chromatographic analysis.

Although the amount of lysine which accumulated in the culture media of resistant mutants was small in comparison with that which has been reported in the literature (Shiio \& Sano, 1969), it is apparent from these results that the removal of exogenously formed lysine could result in a reduction in the growth of Pichia yeast in unsupplemented media. The reason for this reduction is obscure. It is possible that there was an equilibrium between pool and external lysine and that in the presence of the decarboxylase the internal pool was depleted by loss to the medium and protein synthesis impeded. The observation that protein lysine was higher in the resistant mutant, strain PA, suggests that the synthesis of one or more lysinerich proteins occurred. It is possible that the mutation leading to resistance could have 
affected the regulation of synthesis of the lysine-synthesizing system and that one or more of the proteins in this system happened to be lysine-rich. Alternative explanations exist, including the possibility that one mutational event had led to lysine overproduction, and that the elevation of the lysine pool had induced a lysine-rich protein.

\section{REFERENCES}

COTY, V. F. \& LEAvitT, R. I. (1971). Microbial protein from hydrocarbons. Developments in Industrial Microbiology 12, 6I-7I.

Rober ts, B. R., Cowie, D. B., Abelson, P. H., Bolton, E. T. \& Britten, R. J. (1963). Studies of biosynthesis in Escherichia coli. Carnegie Institution of Washington Publication, 607.

Shilo, I. \& Sano, K. (I 969). Microbial production of L-lysine. II. Production by mutants sensitive to threonine or methionine. Journal of General and Applied Microbiology 15, 267-287.

Steele, B. F., Sauberlich, H. E., Reynolds, M. S. \& Baumann, C. A. (1949). Media for Leuconostoc citrovorum 8081. Journal of Biological Chemistry 177, 533-544. 